- production, and many roads built legitimately by logging companies become arteries for illegal agricultural development. As such, logging often serves as a precursor to largescale deforestation.

The simple solution is to avoid tropical wood, but that undercuts the market for timber that is sustainably produced, says Doug Boucher, head of the tropical-forestry programme for the Union of Concerned Scientists in Cambridge, Massachusetts. "This kind of quick and relatively unsophisticated response basically hurts tropical countries, at the expense of the developed world," he says.

Industry and governments have taken steps to improve the market for sustainable tropical wood. The Forest Stewardship Council was launched in 1993 to create an independent certification for sustainably produced timber. More recently, many countries have banned the importation of illegally produced timber. The United States instituted such a ban in 2008. Europe this year went a step further by implementing regulations requiring companies that import wood to establish plans to ensure that the imports are legal. The United Kingdom requires all government-procured wood to be certified as sustainable.

The impact of these initiatives is not yet clear,

\section{TIMBER TRADE}

Analysts expect the US appetite for 'plastic wood' decking materials to increase in coming years.

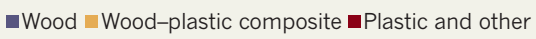

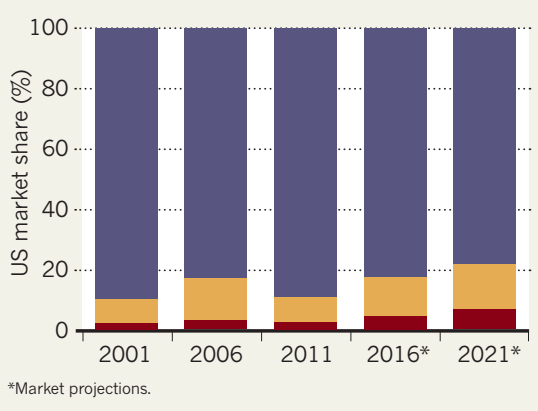

but there are signs of progress. A 2010 study by Chatham House found that illegal logging had dropped by nearly $25 \%$ over the preceding decade, as enforcement efforts increased in tropical countries ${ }^{2}$. But corruption remains a global problem. Many illegal timber exports are going to China, where they are blended into the larger industrial supply chain.

The response to the UK approach suggests a way forward: the law has prompted many major importers in that country to certify the sustainability of their entire supply chains. As much as $80 \%$ of the wood entering the United Kingdom now comes with such assurances, says Brack, and the policy may be shaping broader practices. "The UK government is a big enough consumer of things like office furniture, paper and timber for construction that it has quite a large knock-on effect on the rest $\mathrm{o}_{\mathrm{n}}$ of the market," he says.

Broad numbers aside, a question facing many governments and consumers is whether ipê in particular is being managed sustainably. Some ipê is certified by organizations such as the Forest Stewardship Council, but the overall production data are uncertain. "Is the use of ipê sustainable? No one really knows," Bowyer says. "We are kind of operating in the dark."

At Coney Island, many residents are fighting to protect the signature wooden boardwalk, and the city has acknowledged the historical significance of natural wood in some locations. On a recent weekend, construction crews were busy replacing small sections of boardwalk near the Steeplechase Pier — with fresh ipê. .

1. Bolin, C. A. \& Smith, S. J. Clean. Prod. 19, 620-629 (2011).

2. Lawson, S. \& MacFaul, L. Illegal logging and related trade: indicators of the global response (Royal Institute of International Affairs, 2010).

\title{
Tensions grow as data-mining discussions fall apart
}

Scientists want to exempt computer-based text crawling from Europe's copyright law.

\section{BY RICHARD VAN NOORDEN}

$\mathrm{D}$ isagreement between scientists and publishers has grown on a thorny issue: how to make it easier for computer programs to extract facts and data from online research papers. On 22 May, researchers, librarians and others pulled out of European Commission talks on how to encourage the techniques, known as text mining and data mining. The withdrawal has effectively ended the contentious discussions, although a formal abandonment can be decided only after a commission review in July.

Scientists have chafed for years at limitations on computer-aided research. They would like to use computer programs to crawl over thousands or millions of articles and other online research content, extracting data to build up databases or to pick out patterns such as associations between genes and diseases.

But in many parts of the world, including
Europe, this sort of use currently requires permission from the content's copyright owner. Even if an institution has paid to access a journal, its academics do not necessarily have permission to mine the text. Publishers, worried that their content might be redistributed for free, tend to block data-mining programs, giving extra licence permissions only on a slow, case-by-case basis (see Nature 483, 134-135; 2012). And although authors can now choose to publish under licences that explicitly allow text mining, that innovation doesn't help textminers wanting to run programs on decades of pre-existing content.

Rather than struggle through a thicket of different permissions set by publishers, some researchers want Europe to exempt text mining from copyright law allowing them to run programs on content that they have paid for, and on free content, without fear of copyright breach. Last year, the UK government said that it plans to introduce exemptions for non-commercial purposes. Lenient 'fair use' rights in the United States may already allow text mining, depending on how the law is interpreted.

"There is an intense debate on this within the scientific and research community, with a large number of scientists pointing at the limits of the current copyright regulatory regime," says Ryan Heath, a spokesman for European Commission vice-president Neelie Kroes. "This is a very serious issue, impacting on scientific excellence and innovation in Europe."

To tackle the issue, last December the commission set up a working group - one of a number under a framework called Licences for Europe - to open discussions about new policies among publishers, researchers, librarians and other interested parties, such as technology companies. In late February, researchers complained in a letter to the commission that 
the group was constrained to discuss only textmining licences, and not changes to copyright law (see Nature 495, 295; 2013) - a restriction that would "make computer-based research in many instances impossible".

"Every researcher I've spoken to thinks licensing is a problem," says Susan Reilly, projects manager at the Association of European Research Libraries in the Hague, the Netherlands. She coordinated the letter that declared the 22 May withdrawal from talks. "There was really no point in us continuing to attend," she says. Other signatories include the non-profit Open Knowledge Foundation in Cambridge, UK, and the National Centre for Text Mining at the University of Manchester, UK.

"Continuing the group under current circumstances doesn't make sense," says Heath. "This is regrettable, but at least the process brought to the fore the major controversies in this area." The European Commission, he adds, "will reflect on the implications and will address the matter at the time of the review of the Licences for Europe process in July".

The European talks had always been conflicted because four different European Union administrative departments were involved - not only the department for research and innovation, but also those for education and culture, for media and information issues, and for Europe's internal market, economy and intellectual-property rights. (The May letter argues that the research department is being squeezed out in favour of the others' interests.)

"Since the Licences for Europe process has not managed to deliver in this area, other ways forward must be explored," says Heath. An analysis under way by the commission's internal-market department on the need for copyright reform may provide impetus for action, should it conclude that changes are needed.

Many publishers say that there are practical, as well as legal, barriers to text mining. Even if the practice were permitted through licences or changes to copyright law, researchers would still need a way to access websites without crippling publisher servers through excess traffic. And publishers want to be able to identify the purpose of the programs crawling their content, especially if mining is for commercial means, so as to decide "what they're willing to allow at what cost", says Sarah Faulder, chief executive of the Publishers Licensing Society in London, an industry body that took part in the talks.

To lower some of these practical barriers, the non-profit publisher collaboration CrossRef hopes to launch technology this year enabling text-mining researchers to agree to terms by clicking a button on a publisher's website.

Discussions may have faltered, but scientists and librarians hope to keep talking to officials, says Reilly. "There's lots of disagreement even among publishers," she says. "Some are open to text and data mining, some are completely frightened of it. They need an informed discussion." -

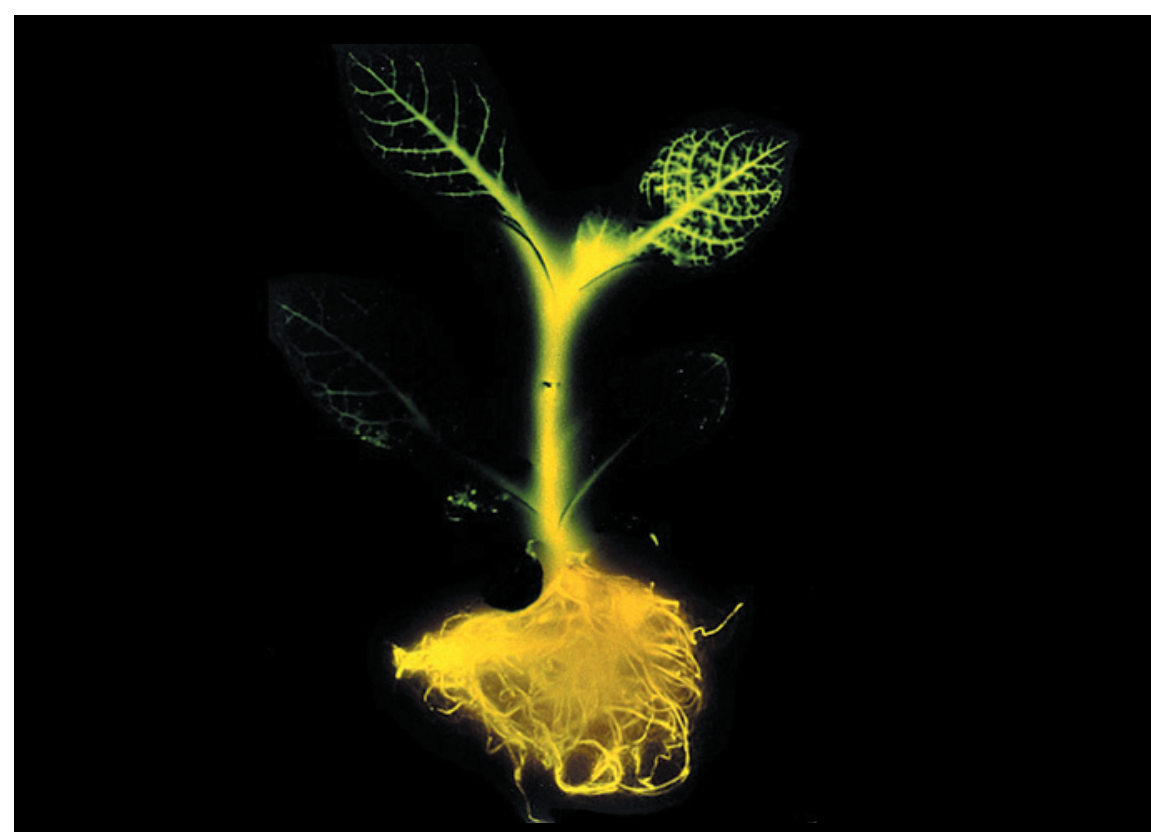

A glow-in-the-dark tobacco plant was first engineered by scientists in the 1980 s.

\section{SYNTHETIC BIOLOGY}

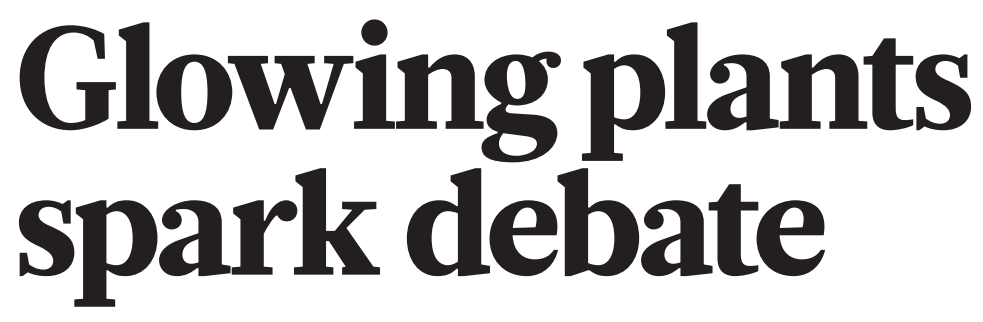

\section{Critics irked over planned release of engineered organism.}

\section{BY EWEN CALLAWAY}

A mong the many projects attracting crowd-sourced funding on the Kickstarter website this week are a premium Kobe beef jerky, a keyboard instrument called a wheelharp and a small leafy plant that will be made to glow in the dark using synthetic-biology techniques.

The Glowing Plant project, which ends its fund-raising campaign on 7 June, seeks to engineer the thale cress Arabidopsis thaliana to emit weak, green-blue light by endowing it with genetic circuitry from fireflies. If the non-commercial project succeeds, thousands of supporters will receive seeds to plant the hardy weed wherever they wish.

The US government has no problem with this prospect, yet some experts and industry watchers are jittery. They fear that distributing the plants could set a precedent for unsupervised releases of synthetic organisms, and might foster a negative public perception of synthetic biology - an emerging experimental discipline that involves genetically engineering organisms to do useful tasks.

The project, based in the San Francisco Bay Area in California, was conceived as a public demonstration of synthetic biology using gene-writing software and lab-made DNA molecules. The effort also reflects a 'DIY biology' movement that seeks to make biotechnology more accessible to the public. "The central goal of the project is to inspire people and educate people about this technology," says entrepreneur and project co-founder Antony Evans.

He and his colleagues - Omri AmiravDrory, founder of synthetic-biology software firm Genome Compiler in Berkeley, California, and Kyle Taylor, a former biology graduate student at Stanford University in California - set out to make Arabidopsis glow because the feat seemed achievable in a simple garage lab. "There are some people in synthetic-biology circles who would yawn at what we're doing," Evans says.

Making plants glow has been possible since the 1980s, when scientists added a gene encoding the firefly enzyme luciferase to a tobacco plant. When sprayed with the chemical substrate luciferin, the plant glowed temporarily (D. W. Ow et al. Science 234, 856-859; 1986). In 2010, another group engineered a tobacco plant to have its own weak glow, using bacterial genes instead (A. Krichevsky et al. 